\title{
Strategic Environmental Assessment of Aragvi River Basin
}

\author{
Nino Sulkhanishvili \\ ${ }^{1}$ Tbilisi State University, Faculty of Exact \& Natural Sciences, Tbilisi, Georgia \\ ${ }^{2}$ ECOVISION -The Union for Sustainable Development, Tbilisi, Georgia
}

Email address:

nino.sulkhanishvili@tsu.ge (N. Sulkhanishvili)

\section{To cite this article:}

Nino Sulkhanishvili. Strategic Environmental Assessment of Aragvi River Basin. American Journal of Environmental Protection. Special Issue: Applied Ecology: Problems, Innovations. Vol. 4, No. 3-1, 2015, pp. 34-37. doi: 10.11648/j.ajep.s.2015040301.16

\begin{abstract}
Integrated Watershed Management System will be gradually introduced in Georgia, according to the EU Association Agreement signed on 27 June, 2014 in Brussels. Integrated Watershed Management System will be based on European principles of river basin management. This paper includes a survey of the Aragvi river basin and deals with the possible environmental, cultural and socio-economic impacts, which might be observed in the basin due to development of small and medium hydro power plants. EU Association Agreement also obliges countries to implement Strategic Environmental Assessment (SEA) for relevant projects and fields. The given paper represents summary of the first in Georgia Strategic Environmental Assessment (SEA) of Aragvi river basin, which aims at supporting governmental policymakers, planners and private investors in the energy sector and other related sectors to make better-informed decisions in order to ensure that national sustainable development policies are addressed in strategic sectoral decision making. The sudy is closely linked to the regional and energy development plans for promotion of renewable energy in Georgia. As set out in the SEA Directive, it will 'contribute to the integration of environmental considerations into the preparation and adoption of plans and programmes with a view to promoting sustainable development'. To achieve this overall aim the study has the following key objectives: To provide the environmental dimension to these plans and thus to contribute to the overall decision making process, which will shape the development of the region as such and more specifically the development of hydroelectric facilities within the region To provide a basis for the subsequent development and appraisal of specific investment projects in the hydroelectric sector in the region; To provide a forum for stakeholders, particularly local residents affected by any hydroelectric development, to participate in the development process To provide potential future investors with information for the most appropriate location and type of hydroelectric facilities and any limitations and conditions which should be met and may be part of the permitting process To provide the authorities with assistance in the appraisal of project proposals put forward by developers The SEA on Aragvi River Basin was commissioned by the European Bank for Reconstruction and Development (EBRD) and carried out by a Consortium consisting of Pöyry Energy GmbH (Consortium Leader), Hydrophil Consulting \& Knowledge Development GmbH, and ECOVISION - The Union of Sustainable Development.
\end{abstract}

Keywords: SEA, Aragvi River Basin, Hydropower potential, Georgia

\section{Introduction}

Environmentally sustainable sources of electricity are increasingly becoming a priority for Georgia government and a business opportunity for national and international developers. Hydro-electric facilities provide a clear environmental benefit by avoiding carbon and other gaseous emissions associated with the fossil based generation. They are supporting national and international efforts to reduce global carbon emissions and may therefore be an important part of a country's energy development strategy. One GWh of electricity produced by Small Hydropower (SHP) may reduce $\mathrm{CO}_{2}$ emissions by up to 480 tonnes.

Nevertheless, hydropower plants are also criticised on environmental grounds, as they can have significant negative impacts, such as the destruction of habitats and associated biodiversity. Cascades of many interconnected hydro-dams and generating facilities can significantly impact a river system or entire catchment area. 
In order to protect the environment from unacceptable changes to landscape, water flow pattern, biodiversity, etc., there is a clear need to complement any hydroelectric development plans by a strategic assessment of the resultant environmental impact. This is particularly important for underdeveloped areas which still have great biodiversity value and natural beauty and therefore a future potential for tourism. The objective is to identify options for new hydropower plants, which are technically feasible, economically viable and environmentally sustainable.

This study is based on the requirements and guidance provided in the respective EU SEA Directive (Directive 2001/42/EC) and supporting documentation. It strives to meet international best practice in SEA and EIA development and takes account of best international industry practise of hydroenergy development.

\section{Study Area}

The most promising sites for small hydropower development in the Aragvi River Basin are located upstream of the Jinvali Reservoir (fig. 1). River morphology, hydrology (water extraction for irrigation and potable water supply) and socio-economic environment (conflict with gravel mining industry and groundwater use) is less favourable downstream of the reservoir. The total hydropower potential in the Aragvi River Basin upstream of Jinvali reservoir is in the order of $250 \mathrm{MW}$.

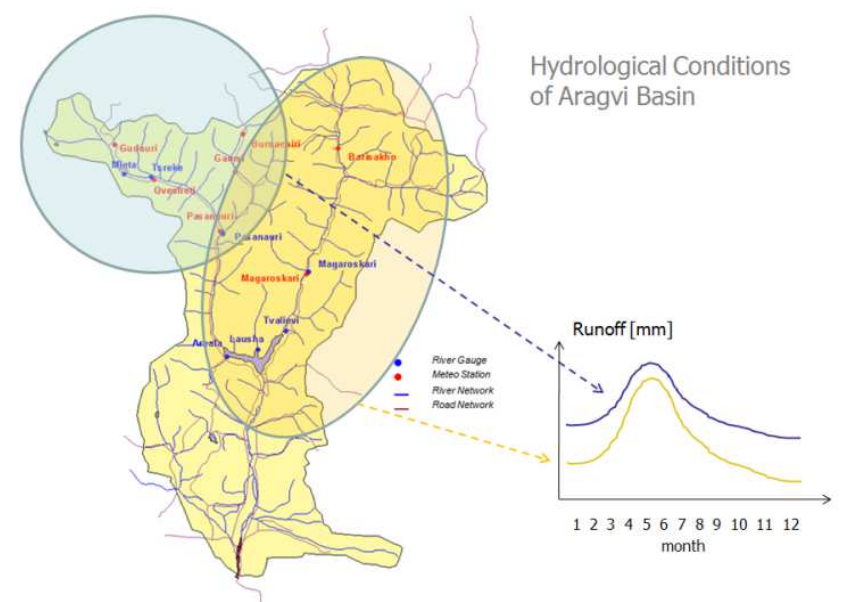

Figure 1. Hydrological Conditions of the Study Area

The study considered only river reaches with a mean annual discharge of over $0.5 \mathrm{~m}^{3} / \mathrm{s}$ and computed for each of them the specific hydropower potential in MW per $\mathrm{km}$. River reaches with high specific potential can be found in the upper reaches of the Tetri Aragvi, the Aragvi downstream of Pasanauri and the lower reaches of the Pshavi Aragvi. However, favourable locations for small hydropower plants might also exist along the river reaches with a lower specific potential. Since the seasonal distribution of runoff is more balanced in the western part of the basin, the sites along the Tetri Aragvi and the Aragvi might be the most interesting locations, but also in the eastern part of the catchment runoff is high with a distinctive maximum from May to July.

Most of the potential sites in the main valleys (Tetri Aragvi, Shavi Aragvi, and Pshavi Aragvi) can be accessed easily by the existing roads (fig. 2). Also, most of the bridges in the main valleys seem to be suitable for traffic during construction. Accessibility to the side valleys is limited, in particular during the winter season.

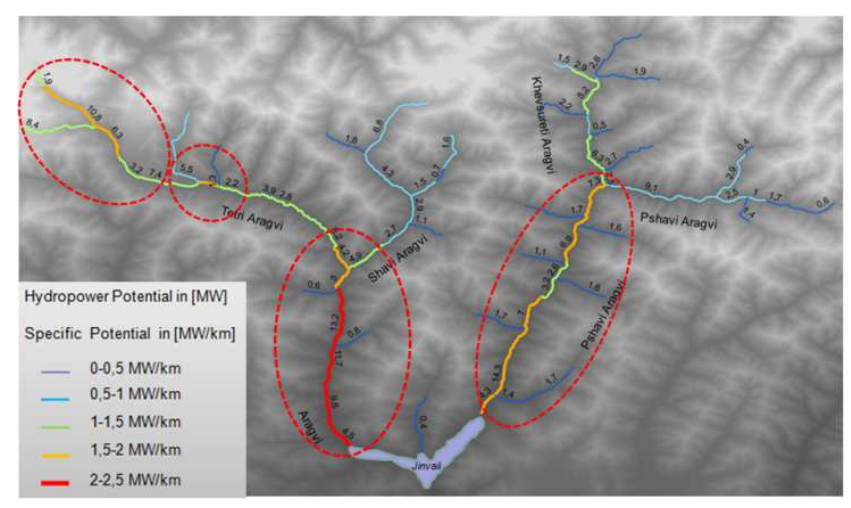

Figure 2. Hydropower potential of the study area

The main challenges for hydropower development are the difficult geological and seismic conditions, the dynamic river flow with large sediment loads and the remote location of some potential hydropower sites.

\section{Results and Discussions}

For development of small hydropower $(<13 \mathrm{MW})$ in the Aragvi River Basin mainly run-off-river schemes shall be considered. Depending on the topography this could be high-head schemes with diversions (in the upper part of the catchment) or low-head schemes with the power house directly at the weir (along the main rivers at the lower part of the catchment). In the upper parts of Pshavi Aragvi and Khevshureti Aragvi the construction of smaller dams for daily or weekly storage might also be considered.

The voltage level of most of the existing transmission lines in Aragvi River Basin is $110 \mathrm{kV}$ or higher, which is appropriate for small hydropower (SHP) development. However, the capacity and the short circuit power of the grid need to be assessed in detail to find out if the system is really suitable for transmission of energy produced by a significant number of new small hydropower plants. Besides, the condition of the existing infrastructure (pylons, overhead lines, substations) needs to be investigated.

A number of possible impacts of small hydropower development on the ecological, cultural and socio-economic environment have been identified. Construction and operation of hydropower plants can change the flow regime of the river and affect downstream aquatic life. Habitats of sensitive plant and animal species may be impaired or destroyed. Cultural heritage sites may be endangered by flooding.

Ecologically sensitive areas have been identified around 
Gudauri, from Mleta to Pasanauri, around Pasanauri, at Jinvali, Kumlistsikhe, and Kaishuri. Downstream of Jinvali almost intact floodplain areas can be found at Saguramo. Protected areas are at Khazbegi and Saguramo. 9 plant and 20 animal species are listed as threatened in the Red Book of Georgia, at least 40 plant species are considered as vulnerable. 37 plants and 18 animal species, including 4 fish species, are Caucasian endemics. 94 plants and 8 animal species are economically valuable. The Ecoregional Conservation Plan for the Caucasus (WWF, 2006) sees the northern part of the basin as Priority Conservation Area.

Dozens of monuments have been discovered in the Tetri and Shavi Aragvi gorges, most of them intact. 74 archeological and cultural sites have been identified so far, especially between Mleta and Pasanauri (fig. 3). Most of them are not located directly by the river side or the valley bottom and are therefore unlikely to be affected by small hydropower development.

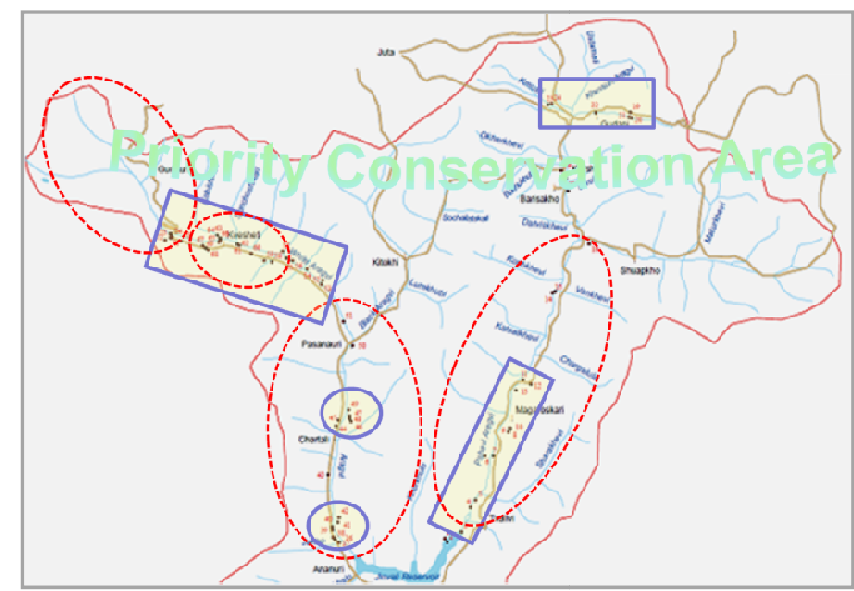

Figure 3. Red dashed circles: favorable places for hydropower plants, red dots: cultural sites, green area: proposed Priority Conservation Area Khevi-Tusheti

Fortunately, small hydropower plants have a much lesser impact on the environment, do not cause most of the potentially severe adverse effects and do not pose a high level of risk compared to large hydropower complexes. Careful selection of location, clearing after construction and revegetation with local seeds can help preserve habitats and restore the ecological equilibrium at a new level

In order to minimize the impact of SHP development on the aquatic life of the Aragvi River and its tributaries, a number of mitigation measures should be taken. This includes construction of fish ladders (suitable for the relevant species) and securing sufficient ecological flow and restoration/rehabilitation of affected river sections.

For SHP projects of significant size a specific EIA, a socio-economic evaluation and an environmental management plan have to be presented. This will require collection of additional and site specific environmental data. Certain information gaps may be closed only by purchasing data. Though this SEA already provides a comprehensive database for future EIAs, some information could not be obtained due to financial limitations.

A prerequisite for hydropower development as well as for environmental monitoring is the rehabilitation of the hydrometric network in the Aragvi River Basin, which was abandoned in the early 1990s. The rehabilitated hydrometric network could also serve as an early warning system for improved management of the Jinvali Reservoir during floods and in case of emergencies.

The study assigned highest priority to the identification of key stakeholders including government organizations, private sector organizations, international organizations, NGOs and, very importantly, local residents and their representatives. A number of meetings were held in the Aragvi River Basin and in Tbilisi. The majority of stakeholders have a positive view of SHP, mainly because of expected lower cost of electricity and accelerated regional business development.

The study undertook a preliminary appraisal of potential benefits and challenges arising from SHP development. It found that besides energy production the main benefit would be some contribution to rural development, such as employment opportunities with higher wages during several years of construction and (to a lesser degree) during operation of the power plants, improvement of road conditions and maintenance (especially during the wintertime), better access to remote villages. The construction of hydropower schemes and the necessary transmission lines will improve the reliability of the power supply at the local scale and potentially reduce the tariff on a long-term view.

Costs arise from plant construction, operation and maintenance, and from required environmental remedies. Revenues can be generated for the investor from energy sales, carbon credits and other services, and, for the Government of Georgia, from taxes and fees. Therefore, if the revenues for the investor are insufficient, the Government could offer some incentives (e.g., tax reductions or subsidies).

Risks for investors are related to transmission infrastructure, electricity bill collection, investment climate, envisaged electricity price deregulation in 2023, cooperation of government agencies and transparency of their rules and decision-making practices, gas and oil prices and availability, and fiscal and legal aspects.

The deteriorating socio-economic situation in the Aragvi River Basin has caused the rural exodus, a decreasing and ageing population, a neglected infrastructure and faltering businesses. Investment in infrastructure, such as power generation and transmission, gas supply lines and roads, could reverse this trend. SHP plants can stimulate regional development by improving the energy balance, reduce energy dependency, facilitate river management and water quality control, create new employment, raise living standards, advance technological standards, transfer knowledge, increase the skills of the workforce and attract further investment and new businesses. 


\section{Conclusions}

First time in the Georgia complex study of river basin was implemented included hydropower potentioal environmenta, social-economic and cultural aspects. As a result it was recommended that small hydropower development in most sensitive areas and remote side valleys upstream shall be avoided to protect the ecological conservation zones. The focus of SHP development $(1-13 \mathrm{MW})$ shall be on the main valleys and a few selected larger and easily accessible side valleys, which are also the most attractive sites from the technical and economic point of view. Mini hydropower $(<1 \mathrm{MW})$ may be considered in smaller side valleys, where settlements already exist.

\section{References}

[1] Strategic Environmental Assessment of Aragvi River Basin, Tbilisi, 2010

[2] EU Georgia Assosiation Agreement, Brussels, June 2014

[3] Strategic Environmental Assesment. Brown and Therivel, 2000
[4] CIA World Fact Book, 2010

[5] World Bank Introduction to the Khudoni Hydropower Project. 2010

[6] WHO Country Brief Georgia, 2010

[7] Christensen, J.H., B. Hewitson, A. Busuioc, A. Chen, X. Gao, I. Held, R. Jones, R.K. Kolli, W.-T. Kwon, R. Laprise, V. Magaña Rueda, L. Mearns, C.G. Menéndez, J. Räisänen, A. Rinke, A. Sarr and P. Whetton, 2007:

[8] IPCC Forth Assessment Report. The Physical Science Basis. Contribution of Working Group I to the Fourth Assessment Report of the Intergovernmental Panel on Climate Change [Solomon, S., D. Qin, M. Manning, Z. Chen, M. Marquis, K.B. Averyt, M. Tignor and H.L. Miller (eds.)]. Cambridge University Press, Cambridge, United Kingdom and New York, NY, USA.2007

[9] Webpage of the Georgian Ministry of Environment and Natural Resources Protection

[10] EU SEA Directive (Directive 2001/42/EC)

[11] The Ecoregional Conservation Plan for the Caucasus, WWF, 2006 